\title{
Niewiedza obywatelska uczniów - nowy problem polonisty?
}

\author{
Citizenship ignorance of pupils - a new problem \\ for a Polish language and literature teacher?
}

\author{
|Bernadeta Niesporek-Szamburska \\ Uniwersytet Śląski, Katowice \\ IORCID: 0000-0001-9935-6733
}

\begin{abstract}
The author presents the problem of school citizenship education. Based on facts from the literature on the subject and the results of a survey of 13- and 16-year-old students, the author indicates their little citizenship knowledge. The author successively refers to the analysis of core curriculas. The apparent richness of content clashes with the results of extensive analyzes of the team of researchers from the School Pedagogy Department of the Nicolaus Copernicus University in Torun, who discovered in the content of the core curricula poverty of categories related to citizenship competencies. Finally, the researcher refers to Polish language educational practices, whose authors (teachers) are able to give citizenship education the right shape and direction.
\end{abstract}

Key words: citizen, citizenship knowledge, school citizenship education, Polish language (as an object)

Streszczenie: Autorka przedstawia w opracowaniu problem szkolnej edukacji obywatelskiej. Opierając się na faktach z literatury przedmiotu oraz na wynikach badania przeprowadzonego wśród 13- i 16-letnich uczniów, wskazuje na ich niewielką wiedzę obywatelską. Kolejno odnosi się do analiz podstaw programowych. Pozorne bogactwo treści zderza z wynikami obszernych analiz zespołu badaczy z Katedry Pedagogiki Szkolnej z Uniwersytetu Mikołaja Kopernika w Toruniu, które odkrywają w treściach podstaw programowych ubóstwo kategorii związanych z kompetencjami obywatelskimi. Na koniec badaczka odwołuje się do polonistycznych praktyk edukacyjnych, których autorzy (nauczyciele poloniści) są w stanie nadać kształceniu obywatelskiemu właściwy kształt.

Słowa kluczowe: obywatel, wiedza obywatelska, szkolna edukacja obywatelska, język polski

Nie ma demokratycznego państwa prawa bez świadomości obywatelskiej u obywatela. Z kolei kształtowanie świadomości obywatelskiej jest niemożliwe bez uświadomienia człowiekowi tego, że jest osobą

(Tischner 1994, 4). 
Polskie społeczeństwo, a zwłaszcza jego młoda część, wykazuje słabą aktywność obywatelską. Z raportu sprzed dziewięciu lat pt. Młodzi 2011 wynika, że badani w wieku od 18 do 24 lat stanowią największy odsetek wśród politycznie biernych (Szafraniec 2011). Brak aktywności potwierdził również Europejski Sondaż Społeczny z 2018 roku (ESS Round 9 2018). Jego wyniki wskazują, że ze wszystkich grup wiekowych najmniej zainteresowani polityką są młodzi Polacy i Polki w grupie wiekowej 15-24 lata $(29,2 \%$ średnio zainteresowanych, 41,9\% słabo zainteresowanych i 24,3\% w ogóle niezainteresowanych) ${ }^{1}$. Młodsza część społeczeństwa wykazuje też coraz mniejszą odporność na populistyczną propagandę. Krystyna Szafraniec pisze: „Mamy do czynienia z zupełnie innym pokoleniem - niedouczonych obywateli, nieznających historii (znających - czasami - fakty, lecz nieznających historii rozumianej jako proces), odbierających współczesność przez pryzmat nienawiści do klasy politycznej i stabloidyzowanych komunikatów medialnych”. Jak twierdzi badaczka: to „efekt socjalizacji politycznej via internet, słaba obecność edukacji obywatelskiej w szkole i osobliwej estetyki dialogu publicznego w Polsce” ${ }^{2}$, czego efektem są: „obywatel[e], ale bez świadomości obywatelskiej" (Arena Idei 2019).

W tym kontekście uzasadnione wydaje się sprawdzenie, jak rozwijane są sprawności stanowiące komponenty kompetencji obywatelskiej (m.in. w jaki sposób przygotowuje się uczniów do praktycznego rozumienia praw człowieka, internalizowania europejskich ideałów wychowania oraz tworzenia podstaw do współpracy między różnymi kulturami (zob. Banach 2000, 14-17), które z nich stały się składnikami programowymi w polskiej edukacji szkolnej - jako że w decydującej mierze szczególną, uwarunkowaną historycznie odpowiedzialność za rozwój kompetencji obywatelskich ponoszą szkoły. Winny one spełniać swój obowiązek poprzez edukację formalną i nieformalną, począwszy od wczesnego wieku szkolnego, i kontynuować ten rodzaj pracy z uczniami w ciągu całego procesu edukacyjnego - wszak obywatelskość wpisano w kompetencje kluczowe edukacji w Europie (por. Branson 1998, 7). Wykonywanie tych zadań powinno odbywać się systematycznie na wszystkich szczeblach kształcenia i znajdować swój wyraz w podstawach programowych edukacji formalnej.

To z pewnością niełatwe zadanie, a planowanie działań edukacyjnych wiązanych z kwestiami kompetencji społecznych i obywatelskich utrudnia fakt niejednoznaczności i zmienności pojęć łączących się tematycznie z obywatelskością. Edukacja, naród, państwo, polityka, obywatel - w różnych miejscach i czasach oznaczały co innego - przez lata były też pod wpływem uwarunkowań historycznych, kulturowych i politycznych Polski.

\footnotetext{
${ }^{1}$ W badaniu wydzielono grupy wiekowe: 15-24 lata, 25-34, 35-44, 45-54, 55-64, 65-74, 74 lata i więcej.

${ }^{2}$ Np. młodzi dwukrotnie częściej niż starsi wykazują chęć wyjścia z Unii Europejskiej, przejawiają lęk przed „uchodźcami-islamistami”, rośnie wśród nich procent bliskich nacjonalizmowi (Szafraniec 2019).
} 
Sama idea obywatelstwa ${ }^{3}$, towarzysząca politycznej i filozoficznej myśli Zachodu od czasu powstania greckich państw miast, wywodzi swe znaczenie z ich nazwy. W języku greckim 'obywatel', wywodzący się z 'miasta' - jako greckiej formy państwowości, społeczności - odnosi się do statusu członkostwa w określonej społeczności (a w wielu przypadkach - w państwie), ale na tym się nie kończy.

W literaturze przedmiotu 'obywatelskość' definiowana bywa w rozmaity sposób w zależności od tradycji i perspektywy filozoficznej autorów czy charakteru i celów prowadzonych przez nich analiz. W dyskursie filozoficznym (w ślad za klasycznymi myślicielami republikańskimi) ujmuje się ją w kategoriach moralnych jako cnotę lub zespół norm i wartości o charakterze etosu, specyficzną etykę lub zbiór pewnych normatywnych i poznawczych cech i dyspozycji jednostek, podkreślając zarazem ich aktywny, działaniowy, praktyczny aspekt - obywatelskość wszak to „bycie” (dobrym) obywatelem (por. Bukowska, Wnuk-Lipiński 2009, 25). W teoriach społeczno-politycznych i psychologiczno-pedagogicznych owa skłonność czy dyspozycja do podejmowania określonych działań definiowana bywa jako postawa, czyli względnie trwały zestaw przekonań, odnoszących się do oznaczonego przedmiotu lub sytuacji, i pozwalająca danej osobie reagować na nie w określony sposób (Bukowska, Wnuk-Lipiński 2009, 25). Definicje obywatelskości $w$ kategoriach postawy łączy się zazwyczaj z obywatelskimi cnotami przejawiającymi się jako przywiązanie do całości społeczeństwa, ochrona i pomnażanie dobra całego społeczeństwa, zbiorowa samoświadomość i samoograniczenie, aktywność, odpowiedzialność i umiejętność współpracy, nastawienie prospołeczne i empatia, zdolność do poświęcania, altruizmu, opiekuńczości. Łączy się ją z wartościami takimi, jak: braterstwo, solidarność, akceptacja równości praw, zaufanie, respektowanie dobra wspólnego, współpraca, przestrzeganie wspólnie ustalonych reguł, podmiotowe traktowanie współobywateli (por. Wnuk-Lipiński 2005, 105). Ujmuje się ją również szerzej jako

Obywatelstwo (...) [to - BNS] wzajemność praw i obowiązków wobec wspólnoty. Obywatelstwo określa członkostwo, członkostwo we wspólnocie, w której jednostka wiedzie swoje życie. Członkostwo zaś nieodmiennie pociąga za sobą określony stopień partycypacji we wspólnocie (Bukowska, Wnuk-Lipiński 2009, 26).

Te trzy aspekty - prawa i obowiązki, przynależność, uczestnictwo - stanowią rdzeń koncepcji obywatelstwa. Obywatelskości nie zaświadczy się więc jedynie formalnoprawnym dokumentem, jej istotą jest świat wartości: dbanie o dobro własnego kraju, co w przypadku młodych ludzi oznacza wdrażanie do odpowiedzialności za radzenie sobie z indywidualnymi i społecznymi problemami, które stają się udziałem dzisiejszych uczniów.

\footnotetext{
${ }^{3}$ Słowo to pochodzi z czeskiego obyvatel, a to z czasownika obývati ,mieszkać’; grecki (gr.

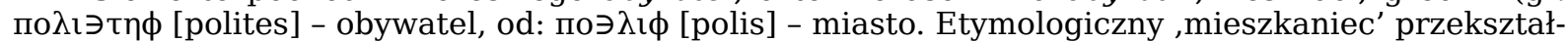
cił się w ,obywatela': osobę oficjalnie uznaną za członka społeczeństwa jakiegoś państwa i mającą wynikające z tej przynależności uprawnienia i obowiązki. Współczesny słownik języka polskiego, https://wsjp.pl/do druku.php?id hasla=5331\&id znaczenia=0 [dostęp: 9.11.2019].
} 
Budząca się aktywność pewnej części młodego pokolenia w ruchu obrony Ziemi zaświadcza najlepiej, że edukacja obywatelska powinna iść z duchem czasu. Inaczej też każą na nią spojrzeć wyzwania postmodernizmu czy nowej humanistyki, bowiem zmiany globalne, w tym masowe migracje, terroryzm, nie rzutują samoistnie na pogłębienie u młodych poczucia obywatelstwa, za to mają wpływ na „poszerzenie”, a równocześnie „spłycenie” poczucia MY (Melosik 2003). Przed polonistą pojawia się więc zadanie włączenia tak rozumianego wychowania obywatelskiego w ponowoczesny kontekst (z możliwością umieszczenia w nim patriotyzmu jako silnego bodźca stymulującego postawy prospołeczne - jeśli spróbuje mu się nadać bardziej utylitarny wymiar (por. Marzęcki 2019, 22).

Spójrzmy, czy tak rozumieją pojęcie 'obywatela', 'obywatelstwa' sami uczniowie. Na pytanie krótkiej ankiety: Kim jest obywatel? - odpowiadali siódmoklasiści (trzynastolatkowie) i uczniowie I klasy liceum (szesnastolatkowie - absolwenci gimnazjum) - w każdej z grup po 40 uczniów (razem - 80 uczniów) $)^{4}$.

Dla większości młodszych respondentów (26 odpowiedzi, 65\% ${ }^{5}$ ) obywatelstwo nie łączy się $z$ żadną ze wskazanych przez badaczy cech, by być obywatelem, wystarczy ${ }^{6}$ :

- być człowiekiem (3); osobq (2); mieszkańcem swojego kraju (13); człowiekiem mieszkajacym $w$ danym mieście, państwie (6); to niekoniecznie patriota - mieszkaniec kraju (1) - 25 odpowiedzi;

- mieć dokument/obywatelstwo: ktoś, kto ma dowód osobisty lub pesel (1); ma obywatelstwo danego kraju (2);

- być osobą, która mieszka w danym kraju i się w nim urodziła (3);

- być osobą mającą pewne prawa: osoba mieszkająca $w$ danym kraju i majaca prawo do oddania głosu w wyborach; osoba majaca obywatelstwo i prawo głosowania w sprawach politycznych (2);

- być osobq mająca obowiązki: ktoś, kto płaci podatki (1);

- obywatel to sługa kraju, to ta osoba, która pomaga krajowi (1).

Połowa starszych uczniów, którzy przeszli już edukację z wiedzy o społeczeństwie, zgodnie optowała za prawnym związkiem między obywatelem i krajem (20 odpowiedzi, 50\%). Pisali oni, że obywatel to:

- osoba posiadajaca obywatelstwo danego państwa (3); osoba przynależna danemu krajowi i posiada obywatelstwo danego kraju (2); osoba zamieszkująca $w$ danym kraju, jest tam zameldowana i posiada obywatelstwo (6); osoba mieszkajaca na danym terytorium, zwiazana więzia prawna z krajem (3); osoba związana

${ }^{4}$ Badanie sondażowe przeprowadziły panie magister: Magdalena Paprotny i Ewelina Zygan w Szkole Podstawowej nr 20 w Rudzie Śląskiej oraz w V Liceum Ogólnokształcącym w Gliwicach.

5 Podobne wyniki uzyskała Mariola Gawrońska, która badała w 2018 roku uczniów trzech klas technikum: $61 \% \mathrm{z}$ nich nie potrafiło zdefiniować pojęcia 'społeczeństwa obywatelskiego'. Por. http://www.spoleczenstwoobywatelskie.edu.pl/ [dostęp: 11.09.2019].

6 Cyfry w nawiasach oznaczają liczbę odpowiedzi tej samej kategorii. Dwie osoby pozostawiły pytanie bez odpowiedzi, jedna napisała: - nie wiem. 
prawnie z danym państwem (2); każdy posiadajacy obywatelstwo danego państwa - jest to uregulowane prawnie (3); ma obywatelstwo, może $\dot{z} y c ́$ poza granicami kraju (1) - $\mathbf{2 0}$ odpowiedzi;

- osoba mieszkajacca $w$ danym kraju (4)/ państwie (4) - 8 odpowiedzi;

- osoba, która jest połaczona z państwem i posiada prawa obywatelskie tego kraju (1);

- mieszkaniec danego państwa, który uznaje i szanuje prawo w nim panujace (1)/ który przestrzega prawa (2); osoba, która posiada obywatelstwo danego kraju. Jest zobowiazany do przestrzegania prawa i obowiązków (2); członek społeczności danego kraju, będacy $w$ zwiazku prawnym z tym krajem, podlegajacy prawom i obowiązkom obywatelskim (1); to mieszkaniec danego państwa. Obywatelstwo to rzecz, która łączy człowieka z państwem. Obywatel zobowiazzany jest do wykonywania obowiązków obywatelskich (1) - 7 odpowiedzi;

- $\quad$ osoba, która mieszka na terenie danego państwa lub się w nim urodziła (1);

- osoba zamieszkujaca dany kraj, która przestrzega jego tradycji, kultury itp. (1).

Wypada zauważyć, że w wielu wypowiedziach na temat bycia obywatelem, zarówno młodszych, jak i starszych respondentów zabrakło wiedzy, iż istotą obywatelstwa są poza prawami i obowiązkami: specyficzny rodzaj przynależności (nie tylko status prawny) oraz uczestnictwo. Obserwacja ta prowadzi do zbadania dzisiejszego kształtu oraz tradycji kształcenia edukacji obywatelskiej w szkole.

Po 1989 roku w Polsce jednym z najważniejszych zadań edukacji stał się właśnie rozwój człowieka i obywatela: starano się zapewnić młodemu pokoleniu dostęp do wiedzy w tym zakresie. Wyzwanie to znalazło swój wyraz w zmianach programowych, najpełniej w reformie z 1999 roku, kiedy w podstawach programowych na trzech etapach nauczania uwzględniono elementy edukacji obywatelskiej (por. Rozp. MENiS 1999). Zaistniała ona na dwóch płaszczyznach, a mianowicie jako:

1. Edukacja obywatelska realizowana w ramach nauczania przedmiotowego, w tym:

a. zintegrowana z treściami różnych przedmiotów;

b. w ramach przedmiotu: wiedza o społeczeństwie, realizowana oddzielnie.

2. Edukacja obywatelska realizowana poza nauczaniem przedmiotowym.

Konkretyzacja w postaci zintegrowanej - poza oddzielnym przedmiotem - zaistniała już na pierwszym etapie edukacyjnym. Treści „obywatelskie” na tym etapie nauczania umieszczono szczególnie w obszarze edukacji społecznej oraz polonistycznej. Na kolejnym, drugim etapie edukacyjnym (klasy 
IV-VI), najbardziej nasycone treściami odnoszonymi do edukacji obywatelskiej były: historia oraz język polski, a także wychowanie do życia w rodzinie. Podobnie w podstawie programowej z 2008 roku: treści nawiązujące do obywatelstwa występowały w szkole podstawowej zakresie przedmiotów: historia i społeczeństwo oraz język polski. Oddzielny przedmiot funkcjonował w 3. klasie gimnazjum. Wprowadzono także oddzielne nauczanie wiedzy o społeczeństwie w szkołach ponadgimnazjalnych w zakresach podstawowym i rozszerzonym, kończące się maturą (podnosiło to rangę samego przedmiotu i kompetencji uzyskiwanych dzięki niemu, jak też dzięki obligatoryjnemu uczestnictwu uczniów w sprzyjającej aktywizacji metodzie projektu), por. Rozp. MEN 2009.

Nowa podstawa programowa z 2017 roku, przywracająca ośmioklasową szkołę podstawową i czteroletnią - ponadpodstawową, wydaje się również programowo doceniać wagę edukacji obywatelskiej. Już w preambule kształcenia ogólnego w szkole podstawowej zaznacza się:

Kształcenie ogólne w szkole podstawowej ma na celu:

1) wprowadzanie uczniów w świat wartości, w tym ofiarności, współpracy, solidarności, altruizmu, patriotyzmu i szacunku dla tradycji, wskazywanie wzorców postępowania i budowanie relacji społecznych, sprzyjających bezpiecznemu rozwojowi ucznia (rodzina, przyjaciele);

2) wzmacnianie poczucia tożsamości indywidualnej, kulturowej, narodowej, regionalnej i etnicznej;

3) formowanie u uczniów poczucia godności własnej osoby i szacunku dla godności innych osób;

4) rozwijanie kompetencji takich, jak: kreatywność, innowacyjność i przedsiębiorczość (s. 5).

Bogactwo treści obywatelskich występuje w treściach nauczania przedmiotowego: wiedzy o społeczeństwie w podstawie dla klasy VIII ${ }^{7}$. Treści te obecne są również $\mathrm{w}$ wyznaczonych dla kształcenia języka polskiego celach, por.:

3. Kształtowanie umiejętności uczestniczenia w kulturze polskiej i europejskiej, szczególnie w jej wymiarze symbolicznym i aksjologicznym.

4. Rozwijanie zdolności dostrzegania wartości: prawdy, dobra, piękna, szacunku dla człowieka i kierowania się tymi wartościami.

5. Kształcenie postawy szacunku dla przeszłości i tradycji literackiej jako podstawy tożsamości narodowej (s. 10);

także w obrębie kształcenia językowego:

1. Rozwijanie rozumienia wartości języka ojczystego oraz jego funkcji w budowaniu tożsamości osobowej ucznia oraz wspólnot: rodzinnej, narodowej i kulturowej.

2. Rozwijanie rozumienia twórczego i sprawczego charakteru działań językowych oraz formowanie odpowiedzialności za własne zachowania językowe.

${ }^{7}$ Treści nauczania umieszczono w następujących grupach tematycznych: społeczna natura człowieka, rodzina, szkoła i edukacja, prawa człowieka, nieletni wobec prawa, społeczność lokalna, społeczność regionalna, wspólnoty narodowe/etniczne i ojczyzna, udział obywateli w życiu publicznym - społeczeństwo obywatelskie, środki masowego przekazu, demokracja w Rzeczypospolitej Polskiej, sprawy międzynarodowe. 


\section{3. (...)}

4. Kształcenie umiejętności porozumiewania się (...) w różnych sytuacjach oficjalnych i nieoficjalnych, w tym także z osobami doświadczającymi trudności w komunikowaniu się (s. 11).

A jednak bogactwo treści ogólnospołecznych - w tym: wyartykułowanych w nowej podstawie kompetencji obywatelskich - nie przekłada się na efekty osiągane przez uczniów i uczennice w wyniku edukacji szkolnej. Odpowiedzi na pytanie, dlaczego treści nie zyskują przełożenia na osiągnięcia, można szukać w analizie wymagań szczegółowych podstaw programowych przeprowadzonej dla wszystkich obligatoryjnych przedmiotów (a dodatkowo dla etyki i wychowania do życia $w$ rodzinie).

Odwołam się do gotowych już pomiarów dokonanych przez toruńskich badaczy z Katedry Pedagogiki Szkolnej Uniwersytetu Mikołaja Kopernika ${ }^{8}$ Autorzy badali przynależne do kompetencji społecznych i obywatelskich wyodrębnione kategorie analityczne efektów w zakresie wiedzy, umiejętności i postaw. Oceniali je zaś pod kątem funkcji, jakie pełni edukacja, a więc funkcji rekonstrukcyjnej (polegającej na przekazywaniu wychowankom odtwarzanej kultury uniwersalnej i narodowej), adaptacyjnej (zasadzającej na wprowadzaniu w zastane role społeczne i zawodowe, w istniejący porządek społeczny) i emancypacyjnej (wynikającej z przygotowania uczniów do przekraczania narzuconych ograniczeń, zmieniania rzeczywistości na lepszą) $)^{9}$.

W badaniach wyodrębniono również przedmioty, w których wystąpiło najwięcej komponentów kompetencji społecznych i obywatelskich. Są to: historia, wiedza o społeczeństwie, historia i społeczeństwo oraz jezyk polski (Kopińska 2018, 140). Wyniki toruńskich badań wskazały też, że w nowej podstawie programowej dla szkoły podstawowej w stosunku do poprzedniej podstawy (z 2008 roku dla szkoły podstawowej i gimnazjum) liczba wymagań wzrosła o ponad 50\% - mimo krótszego o rok okresu nauki ${ }^{10}$. Niekorzystne są również proporcje pomiędzy efektami w zakresie wiedzy, umiejętności i postaw. W nowej podstawie programowej proporcja pomiędzy wymaganiami odnoszonymi do wiedzy a umiejętnościami wynosi

\footnotetext{
${ }^{8}$ Projekt pt. Kompetencje społeczne i obywatelskie $w$ podstawach programowych kształcenia ogólnego. Analiza krytyczna, realizowany w Katedrze Pedagogiki Szkolnej, WNP, UMK w Toruniu przez: Violettę Kopińską, Beatę Przyborowską, Hannę Solarczyk-Szwec, Izabelę Symonowicz-Jabłońską, Kingę Majchrzak, Iwonę Murawską. Por. Kopińska, Solarczyk-Szwec 2017.

9 „Wymagania oceniane jako rekonstrukcyjne to takie, których spełnienie wpisuje się w funkcję rekonstrukcyjną edukacji, polegającą »na odtwarzaniu kultury uniwersalnej i narodowej oraz na przekazywaniu jej wychowankom i na odtwarzaniu struktury społecznej«". Por. Kopińska, Solarczyk-Szwec 2017, 105; Kwieciński 1995, 21. „Wymagania oceniane jako adaptacyjne to takie, których osiągnięcie wpisuje się w funkcję adaptacyjną edukacji, polegającą na »wprowadzaniu ludzi w role społeczne i zawodowe, które zastali i które są do objęcia «" oraz wprowadzaniu w istniejący porządek społeczny, który jednocześnie przedstawiany jest jako dobry i/lub konieczny i/lub niezmienialny”; tamże. Natomiast „wymagania oceniane jako emancypacyjne to takie, których spełnienie wpisuje się w funkcję emancypacyjną edukacji, polegającą na tym, by przygotować ludzi do przekraczania narzuconych ograniczeń, do zmieniania otaczającej rzeczywistości na lepszą"; tamże.

10 Zidentyfikowano 897 wymagań wpisujących się swoim zakresem w kompetencje społeczne i obywatelskie - w stosunku do i tak licznych 569 wymagań obecnych w dotychczasowych podstawach programowych (dla sześcioletniej szkoły podstawowej i gimnazjum łącznie - z 2008 roku) w odniesieniu do przedmiotów: język polski, język obcy nowożytny, historia, matematyka, informatyka, wychowanie fizyczne.
} 
2:1 (w tym zakresie relacja ta w starej podstawie programowej też nie była korzystna: wynosiła 2,5:1). Z kolei aż 3,5 wymagania z zakresu umiejętności przypadają na jedno $\mathrm{z}$ kategorii postaw (w starej podstawie stosunek ten wynosił $2,5: 1)^{11}$. Porównanie podstaw programowych (z 2008 roku, obejmującej gimnazjum, i z 2017 roku) dla klas IV-VIII pod kątem wzajemnych relacji efektów kształcenia ilustruje wykres 1.

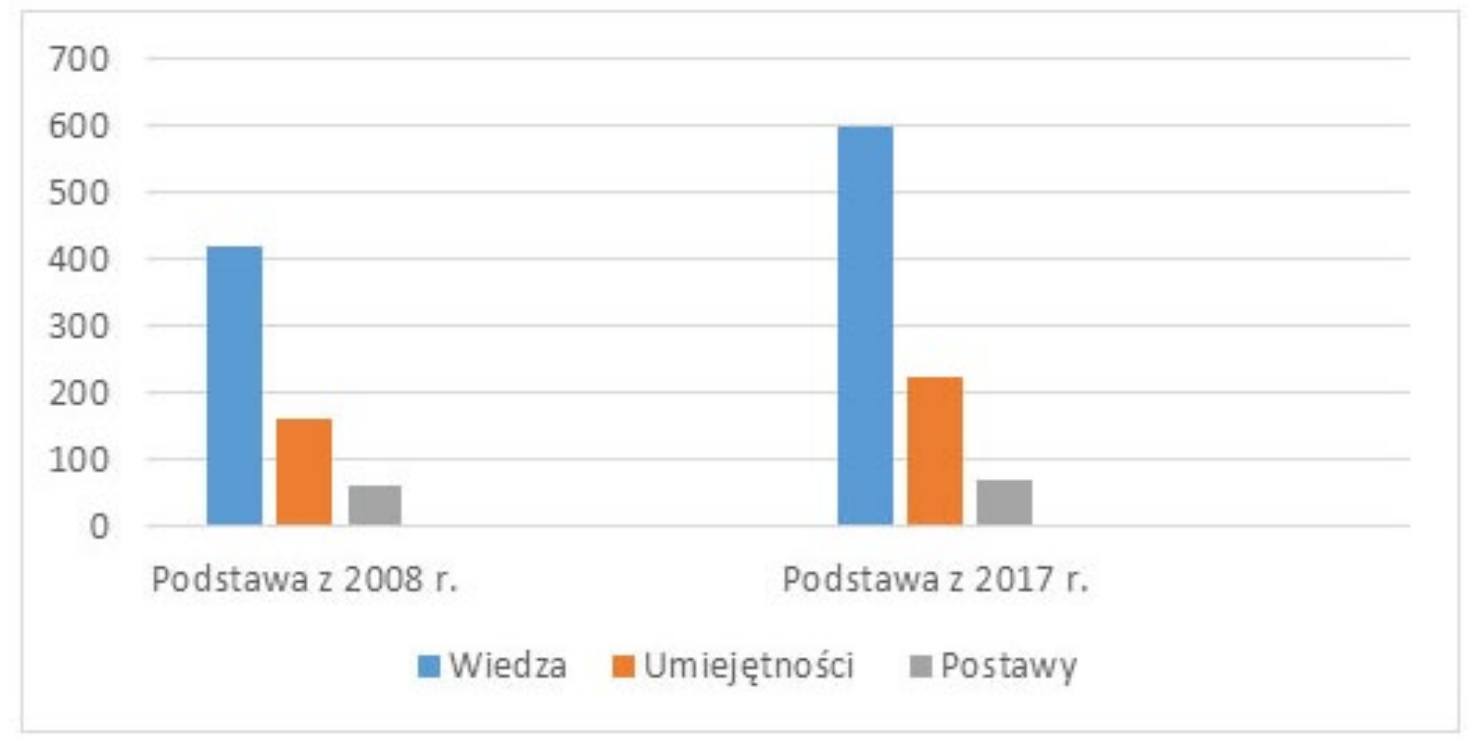

Wykres 1. Porównanie liczby wymagań „obywatelskich” w zakresie wiedzy, umiejętności i postaw w podstawach programowych z 2008 (szkoła podstawowa + gimnazjum) i z 2017 (klasy IV-VIII). Na podstawie danych z: Kopińska 2018, 141-142.

Dysproporcje pomiędzy wiedzą a umiejętnościami oraz pomiędzy umiejętnościami i postawami są znaczące - dominowała i nadal dominuje wiedza, co prowadzi do dysharmonii rezultatów edukacji w zakresie kompetencji obywatelskich i społecznych. Co więcej, gdy badacze przeanalizowali zawarte w "nowej” podstawie kompetencje pod kątem funkcji szkoły/ edukacji, doszli do wniosku, że dominują w niej zdecydowanie wymagania wypełniające funkcje rekonstrukcyjną i adaptacyjną - prowadzące w praktyce do podporządkowania ucznia społecznemu status quo i wstrzymania jego rozwoju ku autentycznej podmiotowości i zdolności samodzielnego podejmowania kwestii o swoje relacje ze światem (por. wykres 2.). Funkcje te odgrywają ważną rolę, choć w „płynnej” rzeczywistości coraz częściej podkreśla się znaczenie trzeciej z nich - funkcji emancypacyjnej, która łączy się z kompetencjami umożliwiającymi podejmowanie działań zmierzających do zmiany własnej sytuacji oraz do świadomego przekraczania indywidualnych granic. Ma ona szczególne znaczenie, gdyż jako:

wyuczalna i dynamiczna sprawność podmiotu (indywidualnego/zbiorowego) wyrażająca się w dostrzeganiu i rozumieniu podmiotowych ograniczeń i deprywacji, świadomym wyrażaniu niezgody na nie, obieraniu dróg ich pokonania i osiągania

${ }_{11}$ Dysproporcje dotyczące liczby wymagań z zakresu kompetencji społecznych i obywatelskich wpisujących się w obszary wiedzy, umiejętności i postaw jeszcze bardziej rosną, jeśli „wyjąć” z obserwowanych kategorii nauczanie wczesnoszkolne (klasy I-III). 
nowych praw i pól wolności oraz odpowiedzialnego korzystania z nich w celu doskonalenia siebie i otoczenia (Czerepaniak-Walczak 2006, 130),

ma wśród wszystkich funkcji największe znaczenie w kształtowaniu postaw obywatelskości.

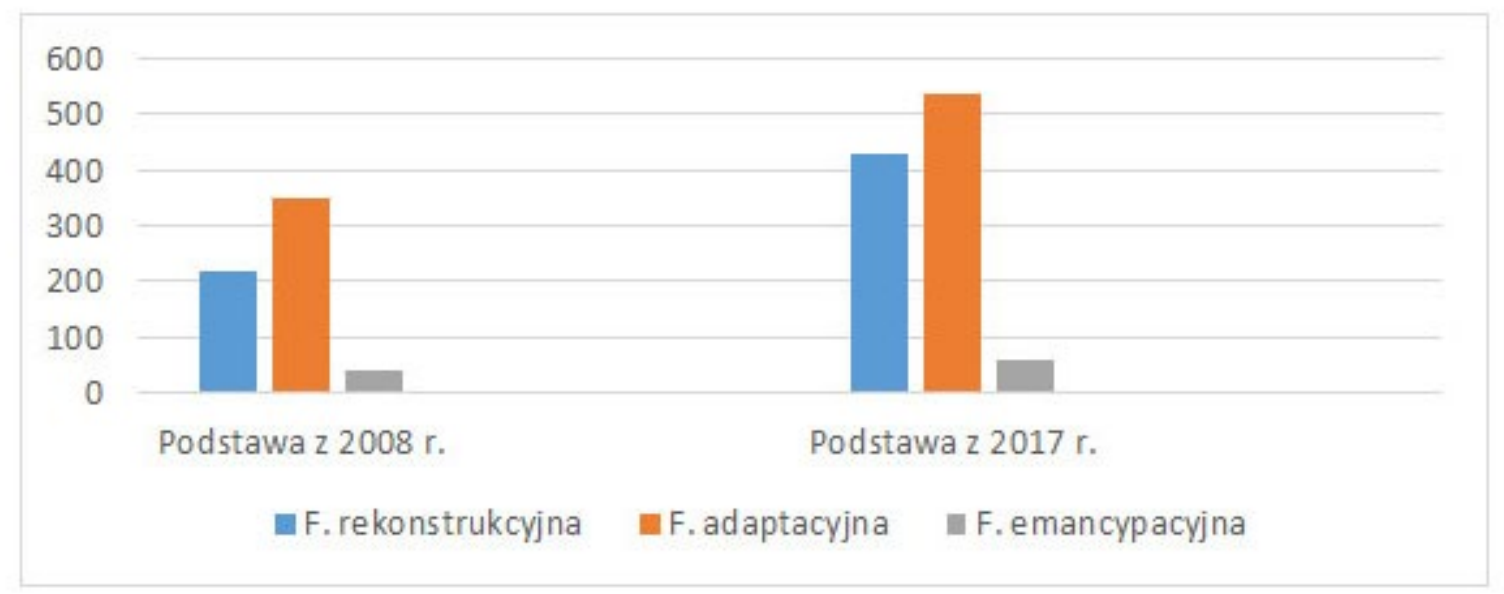

Wykres 2. Porównanie liczby wymagań „obywatelskich” w zakresie przypisywanych im funkcji edukacyjnych (z podstaw programowych z 2008 (szkoła podstawowa + gimnazjum) i z 2017 (klasy IV-VIII). Na podstawie danych z: Kopińska 2018, 143.

Porównanie z podstawą programową z 2008 roku wskazuje jednak, że poza wzrostem liczby wymagań w każdej kategorii ich relacje procentowe do liczby wszystkich wymagań nie uległy zasadniczej zmianie. Podniosła się jedynie liczba wymagań realizujących efekty uczenia się wpisane w rekonstrukcyjną funkcję edukacji (por. tabela 1.).

Tabela 1. Porównanie wymagań obywatelskich i społecznych w zakresie funkcji edukacyjnych w \%

\begin{tabular}{|l|l|l|}
\hline Funkcja edukacji & $\begin{array}{l}\text { Podstawa programowa } \\
\text { z 2008 roku (\% wymagań) }\end{array}$ & $\begin{array}{l}\text { Podstawa programowa } \\
\text { z 2017 roku (\% wymagań) }\end{array}$ \\
\hline rekonstrukcyjna & $38 \%$ & $48 \%$ \\
\hline adaptacyjna & $61 \%$ & $60 \%$ \\
\hline emancypacyjne & $6,8 \%$ & $6,5 \%$ \\
\hline
\end{tabular}

Na podstawie danych z: Kopińska 2018, 144.

Odniesienie do wyników toruńskich badań pozwala również wskazać na szczególnie wyeksponowane, jak i na pominięte treści efektów, czyli występujące najczęściej i najrzadziej w ramowych planach nauczania, a przez to wpływające bardziej lub mniej na uczenie

myślenia krytycznego i twórczego, zdolnego rozpoznawać degradujący nas schemat postępu w realiach gospodarczych i społecznych, oraz pozwalającego ten schemat przekraczać (...), uczyć niezależności w opisywaniu i wyjaśnianiu świata oraz w planowaniu działań (Kwaśnica 2015, 138). 
Można stwierdzić, że $\mathrm{w}$ efektach $\mathrm{w}$ zakresie wiedzy $\mathrm{w}$ podstawie z 2017 roku wciąż dominuje (jak wcześniej) wiedza na temat historii i dziedzictwa kulturowego kraju (w 2008 roku - 20,04\%, w 2017 roku - 20,06\% objętych analizą kategorii) oraz znajomość głównych wydarzeń i trendów w europejskiej i światowej historii, wiedza na temat dziedzictwa kulturowego Europy i świata (choć znaczenie tych treści w odniesieniu do ogólnej liczby analizowanych wymagań w sposób widoczny spadło: 20,04\% - w podstawie z 2008 roku i 10,92\% wszystkich kategorii w 2017 roku; Kopińska 2018, 145).

Wzrosła - w porównaniu z podstawą z 2008 roku - liczba wymagań dotyczących znajomości zasad etyki, jednak ich obecność w efektach uczenia się przedmiotów obowiązkowych jest znikoma (5 wymagań), pozostałe są umiejscowione $\mathrm{w}$ treściach nieobowiązkowego przedmiotu, etyki (45 wymagań) ${ }^{12}$. Nie można więc mówić o ich realnym znaczeniu w edukacji.

W zakresie umiejętności najwyższe wartości - co można by uznać za istotne - osiąga w nowej (także w poprzednio obowiązującej) podstawie programowej umiejętność komunikacyjna: nadawanie i odbieranie komunikatów werbalnych i niewerbalnych, wypełnianie ról komunikacyjnych. Jej znaczenie dotyczące udziału we wszystkich badanych kategoriach jest jednak w podstawie z 2017 roku niższe o połowę od wartości kategorii w podstawie z 2008 roku (6,35\% - 12,13\%; por. Kopińska 2018). Dla aktywności lub pasywności społecznej i obywatelskiej ma też znaczenie, że kompetencje komunikacyjne ucznia realizowane są $\mathrm{w}$ tradycyjnym szkolnym dyskursie: w odniesieniu do transmisji (egzekwowania) wiedzy. W tej sytuacji uczeń nie zdobywa umiejętności rozwiązywania problemów, nie ma też mowy o konstruktywnym porozumiewaniu się, odwadze w publicznej obronie własnego stanowiska czy tworzeniu klimatu zaufania, co wpisywałoby się w emancypacyjną funkcję edukacji.

Wysoką wartość uzyskuje w ramowym planie nauczania umiejętność zachowania się zgodnie $\mathrm{z}$ regułami i zasadami panującymi $\mathrm{w}$ różnych środowiskach. Jej znaczenie zyskało w podstawie z 2017 roku (wzrosło z 1,93\% do 4,57\% wszystkich kategorii, por. Kopińska 2018). Szkoda tylko, że posłużenie się nią nie wychodzi poza kompetencje adaptacyjne - słabo nawiązujące do kompetencji obywatelskich.

W budowaniu postaw najwyższą (choć ogólnie niską) wartość w podstawach uzyskuje kategoria: gotowość do przyjmowania odpowiedzialności wiązanej z uczestnictwem $\mathrm{w}$ różnych wspólnotach, funkcjonowaniem w różnych rolach społecznych - bardziej „doceniona” w podstawie z 2008 roku, a niższa prawie o połowę - w 2017 roku (2,11\% - 1,12\%). Spadła też w ogólnej strukturze badanych wymagań wartość postawy dotyczącej

${ }^{12}$ Dodatkowo jej organizacja w szkołach budzi wiele wątpliwości (dotyczy godzin odbywania przedmiotu, kolidowania z innymi przedmiotami, problemów z zorganizowaniem - etyka odbywa się jedynie w 54\% szkół), por. badania Fundacji „Wolność od Religii” wykonane w 2017 roku. Zob. https://wolnoscodreligii.pl/2018/01/11/raport-badania-ankietowego-dyskryminacja-dzieci-niewierzacych-nieuczestniczacych-lekcjach-religii-rownosc-szkole/[dostęp: 16.10.2019]. 
poszanowania praw człowieka (z 1,23\% do 0,89\%). W porównaniu z planem ramowych z 2008 roku wzrosło za to znaczenie kategorii szacunek dla różnic (odnoszone do różnic kulturowych, religijnych, związanych z kondycją fizyczną ludzi, poglądami i preferencjami muzycznymi; z 0,18\% w 2008 roku do $0,89 \%$ - w 2017 roku), jednak te efekty uczenia się zostały umiejscowione głównie w przedmiotach nieobowiązkowych: w etyce i wychowaniu do życia w rodzinie. Żaden spośród efektów tej kategorii wpisanych w treści przedmiotach obowiązkowych (w sumie 5 efektów) nie znalazł miejsca na języku polskim (por. Kopińska 2018).

$\mathrm{W}$ treściach programowych ramowych planów nauczania (tych starszych i tych najnowszych) można zauważyć wiele „nieobecności”: nie zawierają one kategorii istotnych dla nabywania kompetencji społecznych i obywatelskich. Sporo z nich (w ogóle niewystępujących w nowej podstawie programowej) mogłyby znaleźć swe miejsce na języku polskim (na wszystkich etapach edukacyjnych). W zakresie zasad współżycia społecznego brakuje np.: umiejętności współpracy, a także umiejętności tworzenia klimatu zaufania; gotowości do współdziałania i nawiązywania konstruktywnych relacji oraz ich kształtowania i utrzymywania; pozyskiwania wiedzy na temat empatii i jej znaczenia w kontaktach interpersonalnych; umiejętności życia i pracy w zróżnicowanym środowisku (np. wielokulturowym).

Z kolei kompetencje komunikacyjne należałoby uzupełnić o: umiejętność wyrażania własnego zdania, prezentacji (w mowie i/lub na piśmie) własnych pomysłów; umiejętność rozumienia różnych punktów widzenia; umiejętność konstruktywnego rozwiązywania problemów i porozumiewania się w różnych środowiskach; umiejętność rozwiązywania konfliktów i negocjowania; gotowość zmiany własnej opinii i osiągania kompromisu; zainteresowanie komunikacją międzykulturową.

W kategorii: autonomia, krytyczne myślenie i odpowiedzialność zabrakło: umiejętności oceny stanowiska lub decyzji, zajęcia stanowiska i jego obrony; umiejętności krytycznej oceny informacji i przekazów medialnych, twórczej refleksji; gotowości do działania; gotowości do sprawdzania i korygowania efektów własnej pracy; negatywnej oceny uprzedzeń, rasizmu i dyskryminacji oraz gotowości do pokonywania uprzedzeń; gotowości przyjmowania odpowiedzialności za skutki działań własnych.

„Wzmocnienie” w postaci liczniejszej reprezentacji w treściach programowych przydałoby się także: poszanowaniu praw człowieka (wolność, równość, godność); szacunkowi dla różnic, w tym także różnic płciowych, religijnych i etnicznych.

Kategorie wskazanych braków dowodzą, że mogłyby one stać się przedmiotem budowania nowych umiejętności społecznych na języku polskim czy podczas zajęć pozalekcyjnych, w czasie edukacji nieformalnej. Wynika z nich też, że efektów (w zakresie wiedzy, umiejętności i postaw) w zreformowanym kształceniu w II etapie szkoły podstawowej nie powiązano z przygotowaniem uczniów do uczestnictwa w demokratycznych procesach 
podejmowania decyzji. W chaosie i nadmiarze informacyjnym nowy plan ramowy dla szkoły podstawowej nie zawiera treści uwalniających od dominacji dogmatycznego myślenia, nie eksponuje umiejętności krytycznej oceny (w nowej podstawie odnaleziono tylko 6 takich efektów), nie wzmacnia szacunku dla różnic i wsparcia dla różnorodności, otwartości na różnorodność stanowisk czy jednoznacznie negatywnych ocen wszelkich uprzedzeń i dyskryminacji - tak ważnych w dzisiejszym kontekście. Nadal też nie znajdziemy w planie ramowym uwag o konieczności systematycznego rozwijania umiejętności obrony własnych poglądów wyrażanych publicznie, konstruktywnego porozumiewania się czy gotowości do osiągania kompromisu.

W świetle przypomnianych analiz podstaw programowych nie zaskakują wypowiedzi uczniów dotyczące obywatela i obywatelskości. Trudno się dziwić ich niewiedzy, skoro wartości obywatelskie nie mają wsparcia w edukacji szkolnej - już na poziomie podstaw programowych (por. Kopińska, Solarczyk-Szwec 2016). Smutny obraz kompetencji społecznych i obywatelskich w planach ramowych może się stać zapowiedzią powtórzenia w kolejnej diagnozie społecznej wniosków, które towarzyszyły badaniom sprzed kilkunastu lat: że oto Polska staje się państwem bez społeczeństwa (Czapiński 2006, 7-26).

O treściach kształcenia decyduje podstawa programowa, lecz ostateczny kształt nadaje im organizator edukacji instytucjonalnej, czyli nauczyciel. Dlatego edukacja obywatelska, refleksje na temat społeczeństwa obywatelskiego, mają szanse na zaistnienie na lekcjach języka polskiego. Jak stwierdza młody polonista Tomasz Pawlus,

każda „lekcja polskiego”, na której obecny jest tekst i rozmowa (o tekście i o świecie), w mniejszym lub w większym stopniu, bardziej lub mniej świadomie, dotyka tego problemu. Czytanie w szkole jest bowiem przede wszystkim czynnością odbywającą się dzięki wspólnocie i dzieje się nieustannie w obliczu władzy, czyli zinstytucjonalizowanej pod postacią programu nauczania wiedzy (Pawlus 2018).

Polonista ma potencjalnie wiele możliwości, by kształtowanie u uczniów i uczennic postaw opartych na wartościach obywatelskich nie miało w procesie uczenia się charakteru pobocznego czy marginalnego.

Gwarancją udanej lekcji [polskiego - B.N.S.], na marginesie której aktywizuje się świadomość społeczeństwa obywatelskiego, jest albo maksymalne uwolnienie (się) ucznia spod dominacji wszelkiej siły, która posiada moc opresyjną, albo stworzenie takich warunków dla wymiany myśli, by uczeń mógł bez większych obaw stawiać sensowny opór. Oczywiście na tyle, na ile jest to w ogóle możliwe w przestrzeni szkolnej (Pawlus 2018).

I często nauczyciele wykorzystują materię polonistyczną, stwarzając sytuacje, w których uczniowie:

1. dzięki otwartemu komunikowaniu pracują w atmosferze zaufania, chętni do współpracy z nauczycielem i z rówieśnikami; 
2. mają dostęp do różnych źródeł informacji i różnych punktów widzenia - literatura piękna stwarza w tym względzie optymalne warunki (zob. np. projekt dotyczący ścieżek poznawania Innego na języku polskim, różnych punktów widzenia, możliwości interpretacji; Kuraś 2018);

3. wykorzystują zdobywane wiadomości i umiejętności obywatelskie w życiu codziennym (przez inspiracje do pisania reportaży, felietonów, przeprowadzania wywiadów - form związanych „z życiem”);

4. biorą udział w rozmowach, dyskusjach i debatach na forum klasy czy szkoły ${ }^{13}$, w których każdy może się wypowiedzieć ${ }^{14}$. Jak przekonuje Ewa Jaskółowa, rozmawiając na lekcjach polskiego, „tradycja [literacka - B.N.S.] powinna tworzyć przestrzeń dyskusji, gdyż tylko taki jej kształt sprawi, że będzie czymś »żywym« i ważnym dla uczniów" (Jaskółowa 2018). Edukowanie bowiem

nie polega na przekazywaniu informacji: to nie przelewanie wiedzy z pełnej głowy nauczyciela do pustej głowy ucznia. Każda z tych głów jest już pełna czegoś i nie powinna naginać wszystkich do jednego wzorca (...), lecz przeciwnie, udzielać głosu i wysłuchiwać różnych osób (Sławek 2018);

5. mają realny wpływ na wybrane obszary życia klasy, szkoły, np. współdecydują o sposobach budowania i pozyskiwania wiedzy wykorzystywanej na języku polskim (decydują o doborze lektur, o sposobach uczenia się eksplicytnej wiedzy o języku i jej stosowaniu);

6. budują swoje poczucie wartości i sprawstwa w życiu społecznym oraz zaufanie do innych - to nauczyciel polonista może zainicjować taki proces, współuczestnicząc w tym, co jego podopiecznych interesuje i wykorzystując to w konstruktywnej nauce.

Deficyty w edukacji obywatelskiej mogą więc zostać skompensowane $\mathrm{w}$ praktyce edukacyjnej, dodajmy - praktyce polonistycznej. Istotne dla uczniów i dla przyszłości obywatelskiego kształcenia staje się stworzenie warunków, w których każdego nauczyciela, w tym - polonistę, byłoby stać na odwagę zainicjowania takiej praktyki. Jak bowiem pisała Martha C. Nussbaum, nie wykształcimy wolnych obywateli „dopóki nie ukształtujemy ludzi zdolnych do samodzielnego myślenia, umiejących toczyć spory, rozumiejących różnicę pomiędzy logicznie trafnymi a nietrafnymi argumentami, umiejących odróżnić logiczną formułę argumentacji od treści jej przesłanek" (Nussbaum 2016, 46).

\footnotetext{
13 Powinny się one odbywać jak najwcześniej, np. we Francji czy w Portugalii rozpoczyna się kształcenie obywatelskie w wieku sześciu lat.

${ }_{14}$ Przykładem mogą być organizowane dla uczniów starszych klas szkoły podstawowej i uczniów szkoły ponadpodstawowej debaty oksfordzkie, np. w Katowicach odbywa się Śląski Turniej Debat Oksfordzkich. Turniej wymyśliła i do X edycji organizowała dr Łucja Staniczkowa (w końcu 2019 roku odbywała się XI edycja). Głównym organizatorem było Bractwo Oświatowe Związku Górnośląskiego w Katowicach. Od początku tezy turnieju dotyczyły problemów Śląska: społecznych, politycznych, kulturowych, historycznych. Opiekunami drużyn debatujących (z liceum i gimnazjum) są przeważnie poloniści i historycy, a część debat odbywała się na Wydziale Filologicznym (obecnie: Humanistycznym) Uniwersytetu Śląskiego. Por. https://www.zg.org.pl/imprezy/slaski-turniej-debat-oksfordzkich [dostęp: 11.11.2019].
} 


\section{Bibliografia}

Arena Idei. TVN24, program w dniu 10 listopada 2019 r. https://tvn24.pl/polska/ arena-idei-w-tvn24-sasnal-chwin-zielonka-i-zajadlo-o-tym-czy-demokracjama-przyszlosc-ra984378-2289018.

Banach Czesław, 2000, Edukacja przyszłości, „Res Humana”, nr 2.

Branson Stimmann Margaret, 1998, The Role of Civic Education: A Forthcoming Education Policy Task Force Position Paper from the Communitarian Network. Waszyngton.

Bukowska Xymena, Wnuk-Lipiński Edmund, 2009, Obywatelskość ả la polonaise - czyli jakimi obywatelami sq Polacy?, „Nauka”, nr 1.

Czapiński Janusz, 2006, Polska - państwo bez społeczeństwa, „Nauka”, nr 1.

Czerepaniak-Walczak Maria, 2006, Pedagogika emancypacyjna, Gdańsk.

ESS Round 9: European Social Survey Round 9 Data, 2018, Data file edition 1.2. NSD - Norwegian Centre for Research Data, Norway - Data Archive and distributor of ESS data for ESS ERIC.

Jaskółowa Ewa, 2018, Moderacja panelu dyskusyjnego Praktyczny wymiar edukacji, w: Ficek E., Ochwat M., Sujkowska-Sobisz K., Wójcik-Dudek M. (red.), Społeczeństwo obywatelskie. Edukacja, wartości, style komunikacyjne, Katowice [online], http://www.spoleczenstwoobywatelskie. edu.pl/\#p=37 [dostęp: 11.09.2019].

Kopińska Violetta, Solarczyk-Szwec Hanna (red.), 2017, Kompetencje społeczne i obywatelskie $w$ podstawach programowych kształcenia ogólnego. Analiza krytyczna, Torun.

Kopińska Violetta, Solarczyk-Szwec Hanna, 2016, Edukacja dla wspólnoty? Krytyczna analiza podstaw programowych kształcenia ogólnego, „Forum Oświatowe", vol. 28, no 1.

Kopińska Violetta, 2018, Zmiana polskich podstaw programowych kształcenia ogólnego w zakresie kompetencji społecznych i obywatelskich. Analiza krytyczna, „Parezja”, nr 1.

Kuraś Sylwia, 2018, Historia to uzgodniony zestaw kłamstw. Jak „odkłamać” Innego na lekcjach języka polskiego?, w: Ficek E., Ochwat M., Sujkowska-Sobisz K., Wójcik-Dudek M. (red.), Społeczeństwo obywatelskie. Edukacja, wartości, style komunikacyjne, Katowice [online], http://www.spoleczenstwoobywatelskie.edu.pl/\#p=37 [dostęp: 11.09.2019].

Kwaśnica Robert, 2015, Holistyczna szkoła całodniowa, w: Żakowski J. (red.), Reforma kulturowa 2020-2030-2040. Sukces wymaga zmian, Warszawa.

Kwieciński Zbigniew, 1995, Socjopatologia edukacji, Olecko.

Marzęcki Radosław, 2019, Obywatel patriota? Patriotyzm jako czynnik determinujący aktywność obywatelska młodych Polaków, „Przegląd Politologiczny”, nr 1.

Melosik Zbyszko, 2003, The Teenagers in the Global Consumptions Culture, w: Solarczyk-Ambrozik E., Przyszczypkowski K. (red.), Changing Citizenship, Poznań. 
Nussbaum Martha Craven, 2008, W trosce o człowieczeństwo. Klasyczna obrona reformy kształcenia ogólnego, Męczkowska A. (przeł.), Wrocław.

Pawlus Tomasz, 2018, Ćwiczenia z nieposłuszeństwa, w: Społeczeństwo obywatelskie. Edukacja, wartości, style komunikacyjne, w: Ficek E., Ochwat M., Sujkowska-Sobisz K., Wójcik-Dudek M. (red.), Społeczeństwo obywatelskie. Edukacja, wartości, style komunikacyjne, Katowice [online], http://www.spoleczenstwoobywatelskie.edu.pl/\#p=37 [dostęp: 11.09.2019].

Rozp. MEN w sprawie podstawy programowej wychowania przedszkolnego i kształcenia ogólnego w poszczególnych typach szkół z dnia 23 grudnia 2008 r., Dz.U. 2009, nr 4, poz. 17.

Rozp. MENiS w sprawie podstawy programowej kształcenia ogólnego z dnia 15 lutego 1999 r., Dz.U. 1999, nr 14, poz. 129.

Sławek Tadeusz, 2018, Kuria mać! Śmiech to ostatnia broń nadziei. Rozmowa $z$ prof. Tadeuszem Sławkiem, wywiad Doroty Wodeckiej w „Gazecie Wyborczej" z dnia 31 marca.

Szafraniec Krystyna, 2011, Młodzi 2011, Warszawa.

Tischner Józef, 1994, Rząd i samorzą terytorialny wobec oświaty. Komunikat Biura Krajowego Unii Wolności, Warszawa, 19 maja.

Wnuk-Lipiński Edmund, 2005, Socjologia życia publicznego, Warszawa.

Współczesny słownik języka polskiego [online], https://wsjp.pl/do druku.php?id hasla=5331\&id_znaczenia=0 [dostęp: 9.11.2019].

Wywiad Renaty Kim z Krystyną Szafraniec, „Newsweek Polska”, nr 20/2019, $\mathrm{z}$ dnia 12 maja.

\section{O Autorce}

Bernadeta Niesporek-Szamburska - prof. dr hab., Instytut Językoznawstwa, dyrektor Interdyscyplinarnego Centrum Badań nad Edukacją Humanistyczną, Uniwersytet Śląski w Katowicach. Językoznawczyni i dydaktyk. Zainteresowania badawcze: językowy obraz świata dzieci i młodzieży, język dzieci i młodzieży, literatura dla dzieci i młodzieży, uczenie języka polskiego, także jpjo, nauczanie polonijne, dydaktyka szkoły wyższej. Wybrane publikacje: Vztah jazyka a komunikace v česko-slovensko-polské didaktické reflexi (Karolinum 2019, współaut.), Nauczanie i promocja języka polskiego w świecie: diagnoza - stan - perspektywy (Katowice 2018, współaut.), Stereotyp czarownicy i jego modyfikowanie. Na przykładzie tekstów dla dzieci i wypowiedzi dziecięcych (Katowice 2013), Wiedza o języku i kompetencje językowe uczniów (Katowice 2012), Językowy obraz pór roku i tradycji kulturowych w twórczości dzieci (Katowice 2004), Język wierszy dla dzieci (na materiale „Świerszczyka”) (Katowice 1990); współautorka podręcznika dla dzieci do nauczania języka polskiego jako obcego Bawimy się w polski 1 (Katowice 2009 i n.), współautor: A. Achtelik). 
